\title{
Effect of rearing conditions on astaxanthin accumulation in the white shrimp Penaeus vannamei (Boone, 1931)
}

\author{
Anayeli Quintana-López ${ }^{1}$, Miguel A. Hurtado-Oliva ${ }^{1}$, Marlenne Manzano-Sarabia ${ }^{1}$ \\ Diana J. López-Peraza ${ }^{1}$, Crisantema Hernández ${ }^{2}$, Alejandra García ${ }^{2}$ \& Elena Palacios ${ }^{3}$ \\ ${ }^{1}$ Facultad de Ciencias del Mar, Universidad Autónoma de Sinaloa, Mazatlán, Sinaloa, México \\ ${ }^{2}$ Centro de Investigación en Alimentación y Desarrollo, Mazatlán, Sinaloa, México \\ ${ }^{3}$ Centro de Investigaciones Biológicas del Noreste, Instituto Politécnico Nacional \\ La Paz, Baja California Sur, México \\ Corresponding author: Miguel A. Hurtado-Oliva (mholiva@uas.edu.mx)
}

\begin{abstract}
Astaxanthin is an essential micronutrient that regulates shrimp physiology, acting as a free radical scavenger, increasing stress resistance, and enhancing the immune response, improving growth and survival in farm-raised organisms. Despite this, accumulation of astaxanthin has not been evaluated regarding rearing conditions of shrimp. Thus, this study aimed to assess the effect of rearing conditions (extensive vs. hyperintensive) in the accumulation of astaxanthin in tissues of shrimp Penaeus vannamei, using wild juveniles as a reference of the levels of astaxanthin present in the natural environment. The main oxycarotenoid found was astaxanthin, which was mostly accumulated in hepatopancreas $(>90 \%)$ in esterified form, while mostly free astaxanthin was found in exoskeleton and muscle $(<60 \%)$. Comparing wild and reared shrimp, the content of esterified astaxanthin was significantly higher in the hepatopancreas of shrimp reared under extensive conditions $\left(191.45 \pm 23.08 \mu \mathrm{g} \mathrm{g}^{-1}\right)$ followed by wild shrimp $\left(144.08 \pm 13.92 \mu \mathrm{g} \mathrm{g}^{-1}\right)$, while low values $\left(3 \pm 1 \mu \mathrm{g} \mathrm{g}^{-1}\right)$ were found in shrimp reared under hyper-intensive conditions. Astaxanthin levels found in farm-raised shrimp were not explained by commercial feeds, since no astaxanthin (only traces of its chemical precursor $\beta$-carotene), was found in the six different commercial feeds analyzed for rearing shrimp. Thus, the results may be explained by primary productivity (i.e., phytoplankton) that is consumed as natural food by shrimp in the ponds of farming systems, or by the effect of specific rearing conditions on the microbiota associated with carotenogenesis in the gut of shrimp. In any case, commercial feeds should fulfill all nutritional requirements for shrimp, particularly under stressful conditions as it occurs in hyper-intensive farming.
\end{abstract}

Keywords: Penaeus vannamei; astaxanthin; commercial feed; crustacean; carotenoids; aquaculture

\section{INTRODUCTION}

Shrimp production by aquaculture practices has been taking place in Mexico since the early ' 80 s. Nowadays, commercial production is $c a$. $130,000 \mathrm{t}$, which is about $57 \%$ of total shrimp production, this including fishery and aquaculture (FAO, 2018), due to the increasing larvae supplier laboratories, but also by considerable advances in knowledge of the biology of this species, including pathology, control of the reproduction and growing by genetics technics, advances in nutrition, among others. All these aspects have improved and modernized the farming of shrimp at significant levels worldwide.
Astaxanthin is commonly used as a source of pigment to increase the characteristic reddish color of fish and shrimp in culture (Foss et al., 1984; Arredondo-Figueroa et al., 2003). Pigments in penaeid shrimp include carotenes and xanthophylls such as astaxanthin and their esters (Fisher et al., 1957). Astaxanthin (3,3'-dihydroxy- $\beta, \beta$-carotene-4,4'-dione) belongs to the terpenes group, and its large polyunsaturated carbon chain allows different physiological and biological functions in aquatic organisms. Carotenoids have been reported to enhance growth and survival of penaeid shrimp, including the white shrimp Penaeus vannamei (Chien et al., 1999; Supamattaya et al., 2005; Zhang et al., 2013). Astaxanthin has been

Corresponding editor: Fernando Vega-Villasante 
considered an essential growth factor during early development of shrimp (Dall et al., 1995) and it also acts as an antioxidant by inactivation of free radicals (Chew, 1995). The antioxidant activity of astaxanthin is superior to that of $\beta$-carotene, vitamin $C$, or vitamin E (Shimidzu et al., 1996), which is important when free radicals surpass the endogen antioxidant capacity, increasing resistance to stress and enhancing the immune response (Estermann, 1994). Like vitamin E, astaxanthin and other lipophilic carotenoids protect cell membranes by decreasing lipid peroxidation (Chien \& Jeng, 1992).

Shrimp cannot synthesize carotenoids de novo but seems that they are capable of transforming carotenoids from food (i.e., $\beta$-carotene) and storing them in the tissues as astaxanthin (Moaka, 2011). The main sources of carotenoids used in aquaculture are algae Haematococcus pluvialis (Ju et al., 2011), red pepper Capsicum annum (Arredondo-Figueroa et al., 2003), or synthetic carotenoids (Niu et al., 2009), which have been added in concentrations of 80 to $250 \mathrm{mg} \mathrm{kg}^{-1}$ to experimental shrimp feeds (Flores et al., 2007). However, the accurate inclusion level in balanced commercial shrimp feeds is still unknown, even for the most reared species. Therefore, carotenoid levels and particularly the content of free and esterified astaxanthin should be assessed in wild shrimp populations.

So far, total carotenoids have been reported in exoskeleton of adult wild and farmed Indonesian shrimp Penaeus monodon with an average value of 25.3 mg kg-1 (Howell \& Matthews, 1991), and in muscle and hepatopancreas of wild Pandalus montagui with an average of 21 and $72 \mathrm{mg} \mathrm{kg}^{-1}$, respectively (Clarke, 1979). Higher content of total carotenoids and free astaxanthin levels were assessed in the hepatopancreas of wild (5.9 to 9.6 and 3.9 to $5.8 \mu \mathrm{g} \mathrm{g}^{-1}$ ) compared to rear (2.3 to 3.8 and 1.2 to $1.6 \mu \mathrm{g} \mathrm{g}^{-1}$ ) adult shrimp $P$. vannamei (Liñán-Cabello et al., 2003). However, these data were obtained by spectrophotometric techniques, and more accurate analyses should be performed in order to obtain both free and esterified astaxanthin contents.

Thus, this study aimed to assess the effect of rearing conditions (extensive $v s$. hyper-intensive) in the accumulation of astaxanthin in tissues of shrimp $P$. vannamei, using wild juveniles as a reference of the levels of astaxanthin present in the natural environment.

\section{MATERIALS AND METHODS}

\section{Shrimp sampling}

Wild juveniles (average weight of $8.6 \pm 0.6 \mathrm{~g}$ ) of $P$. vannamei were captured during the fishing season in
September 2016 in Huizache-Caimanero, a lagoon system located in southern Sinaloa, Mexico. The second group of shrimp (average weight of $9.0 \pm 0.3 \mathrm{~g}$ ) reared under extensive conditions were obtained from three different ponds in a shrimp farm located in Mazatlán, Sinaloa, Mexico. The rearing conditions were as follows: $10 \%$ water exchange once a week, salinity 45 , temperature $29 \pm 2{ }^{\circ} \mathrm{C}$. Shrimp were reared in 2.5 ha land ponds at a density of 15 ind $\mathrm{m}^{-2}$. The commercial feed was supplied once a day (3\% body weight). For increasing primary productivity (i.e., phytoplankton) of the ponds, agricultural fertilizers were used monthly. The third group of shrimp (average weight of $8.2 \pm 0.3 \mathrm{~g}$ ) reared under hyper-intensive conditions were provided from three different ponds by a local commercial larvae supplier laboratory, the rearing conditions were as follows: $2000 \mathrm{~m}^{3}$ rectangular geo-membrane tanks at a density of 400 ind $\mathrm{m}^{-3}, 5 \%$ water exchange once a month, salinity 33 , temperature $29 \pm 2^{\circ} \mathrm{C}$. Biofloc technology system (BTS) was used during the first two weeks and then crumbled, and pelleted feed was supplied every $4 \mathrm{~h}$ a day $(2.5 \%$ of body weight). All shrimp, wild and reared were quickly frozen in dry ice and shipped to the laboratory, then stored at $-70^{\circ} \mathrm{C}$ for further analysis. All shrimp were thawed and dried with paper towels, and whole body and separated tissues (hepatopancreas, exoskeleton, and muscle) were weighed.

\section{Food sampling}

Pigment content in commercial shrimp feeds of different brands used in the extensive and hyperintensive systems was analyzed in order to assess the contribution of pigments in the tissues of reared shrimp. These commercial feeds were: 1) pelletized for extensive conditions (Feed-Ext) with $30 \%$ protein (Brand A), 2), pelletized for hyper-intensive conditions (Feed-Hyper) with 35\% protein, 3) crumble FeedHyper with 35\% protein, 4) Feed-Ext with $30 \%$ protein (Brand B), 5) Feed-Ext with 40\% protein, and 6) FeedExt with $35 \%$ protein.

\section{Analysis of pigments}

All shrimp tissues and $1 \mathrm{~g}$ of each commercial feed were homogenized on ice in $3-5 \mathrm{~mL}$ of $90 \%$ acetone to remove carotenoids and stored at $4{ }^{\circ} \mathrm{C}$ avoiding exposure to light. After $24 \mathrm{~h}$ the supernatant was recovered by centrifugation $\left(3200 \mathrm{~g}, 10 \mathrm{~min}\right.$ at $\left.4^{\circ} \mathrm{C}\right)$ and stored at $-70^{\circ} \mathrm{C}$ until analysis. Identification and quantification of pigments was determined according to the method described by Zapata et al. (2000) with the following modifications: the carotenoids were analyzed on an HPLC (Agilent Technologies 1200 Infinity Series) equipped with a Zorbax C8 column $(4.6 \times 100$ 
mm, $3.4 \mu$ particle size) and diode-array detector (DAD). The temperature of the column was maintained at $25^{\circ} \mathrm{C}$. The mobile phases were: eluent $\mathrm{A}$, methanol: acetonitrile: an aqueous solution of pyridine $0.25 \mathrm{M}$ (50:25:25, v:v:v), while eluent B was methanol: acetonitrile: acetone (20:60:20, v:v:v). The flow rate was set at $1 \mathrm{~mL} \mathrm{~min}{ }^{-1}$. The organic solvents used to prepare the mobile phase were HPLC grade (Tedia, $\mathrm{OH}$, USA) and were filtered through $0.45 \mu \mathrm{m}$ membrane filters. Carotenoids were identified by comparing their retention times with those of standards (DHI, Hoersholm, Denmark), and using their specific absorption spectra. Quantification was assessed according to calibration curves of each standard pigment and data are expressed in $\mu \mathrm{g} \mathrm{g}^{-1}$ of wet tissue (shrimp) or $\mu \mathrm{g}$ $\mathrm{g}^{-1}$ in dry weight (commercial feeds).

\section{Statistical analysis}

One-way analysis of variance (ANOVA) was performed using the origin of shrimp (wild or reared) as the independent variable and the concentration of carotenoids obtained in each tissue (hepatopancreas, exoskeleton, and muscle) of the shrimp as a dependent variable. ANOVA was followed by the Tukey post-hoc test to evaluate significant differences $(P<0.05)$ between means. All data were expressed as mean \pm SE, standard error. The statistics were performed with the software Statistica v.10 (Statsoft, Inc., Tulsa, OK).

\section{RESULTS}

\section{The content of carotenoids in wild and reared shrimp}

Significant differences $(P<0.01)$ in carotenoid content was observed regarding the origin (wild vs. reared) for each shrimp tissue (Table 1). Esterified astaxanthin was higher in the hepatopancreas of shrimp reared under extensive conditions $\left(192 \pm 23 \mu \mathrm{g} \mathrm{g}^{-1}\right)$, followed by wild shrimp (144 $\left.\pm 14 \mu \mathrm{g} \mathrm{g}^{-1}\right)$, with very low values (2.8 $\left.\pm 0.9 \mu \mathrm{g} \mathrm{g}^{-1}\right)$ in the hepatopancreas of shrimp reared under hyper-intensive conditions. In contrast, free astaxanthin was higher $\left(23 \pm 4 \mu \mathrm{g} \mathrm{g}^{-1}\right)$ in the hepatopancreas of shrimp obtained from the wild, compared to shrimp reared under hyper- and extensive conditions $\left(0.5\right.$ to $\left.7 \mu \mathrm{g} \mathrm{g}^{-1}\right)$. Similar results were also observed for $\beta$-carotene, with higher significant values $\left(12.2 \pm 1.2 \mu \mathrm{g} \mathrm{g}^{-1}\right)$ in the hepatopancreas of wild shrimp, compared to shrimp reared under hyper- and extensive conditions ( 0.2 to $\left.5.8 \mu \mathrm{g} \mathrm{g}^{-1}\right)$. Trace values $\left(<3 \mu \mathrm{g} \mathrm{g}^{-1}\right)$ of zeaxanthin and canthaxanthin were detected in the hepatopancreas of wild shrimp, as well fucoxanthin $\left(0.12 \mu \mathrm{g} \mathrm{g}^{-1}\right)$ and zeaxanthin $\left(0.10 \mu \mathrm{g} \mathrm{g}^{-1}\right)$ in the hepatopancreas of shrimp reared under hyper-intensive conditions. In hepatopancreas, both fractions of astaxanthin (esterified and free) compromised about 90 and 4 to $39 \%$, respectively of total pigments assessed in this tissue (Fig. 1a).

In exoskeleton, the content of esterified astaxanthin was significantly higher $\left(17.07 \pm 3.21 \mu \mathrm{g} \mathrm{g}^{-1}\right)$ in shrimp reared under extensive conditions (Table 1), with lower values in wild shrimp $\left(0.74 \pm 0.49 \mu \mathrm{g} \mathrm{g}^{-1}\right)$ and reared under hyper-intensive conditions $\left(2.61 \pm 0.53 \mu \mathrm{g} \mathrm{g}^{-1}\right)$. No significant differences were observed in the content of free astaxanthin. $\beta$-carotene was assessed in the range of 0.08 to $1.01 \mu \mathrm{g} \mathrm{g}^{-1}$, with higher values in the exoskeleton of shrimp reared under extensive conditions. The percentage of free astaxanthin was higher in exoskeleton of wild shrimp (60\%) and shrimp reared under hyper-intensive conditions (53\%), while esterified astaxanthin was predominant in exoskeleton of shrimp reared under extensive conditions (87\%), and similar proportions of both fractions of astaxanthin (free and esterified) were assessed in shrimp reared under hyper-intensive conditions (54 and 44\%, Fig. 1b).

Very low quantities of carotenoids $\left(<2 \mu \mathrm{g} \mathrm{g}^{-1}\right)$ were detected in muscle (Table 1). Esterified astaxanthin was higher $\left(1.67 \pm 0.22 \mu \mathrm{g} \mathrm{g}^{-1}\right)$ in shrimp reared under extensive conditions, with lower values in both wild shrimp and reared in hyper-intensive conditions ( $c a$. $\left.0.60 \mu \mathrm{g} \mathrm{g}^{-1}\right)$. No significant differences were observed in the content of free astaxanthin in the muscle of shrimp, both wild and reared. Trace values ( 0.02 to 0.09 $\mu \mathrm{g} \mathrm{g}^{-1},<5 \%$ of total carotenoids, Fig. 1c) of zeaxanthin, canthaxanthin, and $\beta$-carotene were also detected.

\section{Carotenoid content in commercial feeds}

No astaxanthin was detected in any of the six different feed samples analyzed, only zeaxanthin was detected $\left(<4 \mu \mathrm{g} \mathrm{g}^{-1}\right)$, as well very small quantities of $\beta$-carotene $\left(<1 \mu \mathrm{g} \mathrm{g}^{-1}\right)$ (Fig. 2).

\section{DISCUSSION}

Esterified astaxanthin composed more than $90 \%$ of total carotenoids assessed in reared shrimp under extensive conditions and wild shrimp, but not in shrimp reared under hyper-intensive conditions (Fig. 1), in accordance to previous results where higher content of esterified astaxanthin was assessed in wild shrimp of Penaeus vannamei (62\%), P. monodon (98\%), P. japonicus (79\%) and Metapenaeus monoceros (72\%, Scheidt, 1990). Higher accumulation of esterified astaxanthin in the reared shrimp, even above of values of observed in the wild shrimp (Table 1), could represent a physiological advantage in rearing shrimp that should be further tested in experimental trials; as well in commercial production, particularly during 
Table 1. Pigment concentration ( $\mu \mathrm{g} \mathrm{g}^{-1}$ wet weight) in hepatopancreas, exoskeleton, and muscle of Penaeus vannamei captured in the wild and reared in extensive (Reared-Ext) and hyper-intensive conditions (Reared-Hyper).

\begin{tabular}{lccccc}
\hline \multirow{2}{*}{ Tissue } & \multirow{2}{*}{ Pigment } & \multicolumn{4}{c}{ Origin } \\
\cline { 3 - 6 } & Wild & Reared Ext. & Reared hyper & $P$ \\
\hline Hepatopancreas & Astaxanthin F & $22.82 \pm 4.19 \mathrm{a}$ & $6.95 \pm 0.52 \mathrm{~b}$ & $0.54 \pm 0.04 \mathrm{c}$ & 0.01 \\
& Astaxanthin E & $144.1 \pm 13.9 \mathrm{~b}$ & $191.5 \pm 23.1 \mathrm{a}$ & $2.8 \pm 0.9 \mathrm{c}$ & 0.01 \\
& Fucoxanthin & nd & nd & $0.12 \pm 0.02$ & - \\
& Zeaxanthin & $2.96 \pm 0.46 \mathrm{a}$ & nd & $0.10 \pm 0.01 \mathrm{~b}$ & 0.01 \\
& Canthaxanthin & $3.23 \pm 0.45$ & nd & nd & - \\
& $\beta$-carotene & $12.2 \pm 1.20 \mathrm{a}$ & $5.8 \pm 0.75 \mathrm{~b}$ & $0.2 \pm 0.03 \mathrm{c}$ & 0.01 \\
\hline Exoskeleton & Astaxanthin F & $1.51 \pm 0.11$ & $1.81 \pm 0.27$ & $2.29 \pm 0.37$ & $\mathrm{~ns}$ \\
& Astaxanthin E & $0.74 \pm 0.49 \mathrm{~b}$ & $17.07 \pm 3.21 \mathrm{a}$ & $2.61 \pm 0.53 \mathrm{~b}$ & 0.01 \\
& Zeaxanthin & $0.06 \pm 0.01$ & nd & $0.07 \pm 0.01$ & $\mathrm{~ns}$ \\
& Canthaxanthin & $0.04 \pm 0.01$ & nd & $\mathrm{nd}$ & - \\
& $\beta$-carotene & $0.55 \pm 0.08 \mathrm{~b}$ & $1.01 \pm 0.19 \mathrm{a}$ & $0.08 \pm 0.02 \mathrm{c}$ & 0.01 \\
\hline Muscle & Astaxanthin F & $0.73 \pm 0.04$ & $0.57 \pm 0.08$ & $0.58 \pm 0.06$ & $\mathrm{~ns}$ \\
& Astaxanthin E & $0.63 \pm 0.07 \mathrm{~b}$ & $1.67 \pm 0.22 \mathrm{a}$ & $0.60 \pm 0.14 \mathrm{~b}$ & 0.01 \\
& Zeaxanthin & $0.03 \pm 0.01$ & $0.02 \pm 0.01$ & $0.03 \pm 0.01$ & $\mathrm{~ns}$ \\
& Canthaxanthin & $0.02 \pm 0.01$ & nd & $\mathrm{nd}$ & - \\
& $\beta$-carotene & $0.09 \pm 0.04$ & $0.07 \pm 0.01$ & $0.04 \pm 0.1$ & $\mathrm{~ns}$ \\
\hline
\end{tabular}

Results are expressed as the mean \pm SE and were analyzed by one-way ANOVA followed by a Tukey test to assess significant differences. Means not sharing the same letters indicate significant differences $(P<0.01)$. Total shrimp analyzed $\mathrm{n}=133$, nd: values not determined, ns: non-significant values. $\mathrm{F}$ : free, E: esterefied.

rearing hyper-intensive conditions. Mono- and diester astaxanthin accumulates in shrimp tissues of $P$. monodon after specific concentration of total carotenoids is reached, suggesting that these both chemical forms are storing as reserves of astaxanthin (Okada et al., 1994). Reserves of astaxanthin could be helpful during the stressing conditions that occur during shrimp rearing. In this sense, shrimp reared under extensive conditions may be in better health condition, since higher content of esterified astaxanthin was found in the three tissues analyzed (e.g., hepatopancreas, exoskeleton, and muscle) compared to shrimp reared under hyper-intensive conditions (Table 1). Moreover, the lower content of astaxanthin could explain the lower and equal proportion of free and esterified astaxanthin assessed in the three tissues of shrimp reared under hyper-intensive conditions (Fig. 1).

Differences in the accumulation of astaxanthin in shrimp reared under extensive and hyper-intensive conditions could be attributed to higher concentrations and availability of carotenoids that usually occur in the natural environment, including the ponds in aquaculture systems. For instance, the natural diet of shrimp consists mainly of small gastropods, bivalves, and crustaceans (Dall et al., 1991), which contain a wide range of carotenoids (Goodwin, 1984). In estuarine conditions, juvenile shrimp may also feed on primary producers (i.e., micro- and macroalgae, mangrove leaves, and seagrasses, among others). Which is particularly important for shrimp farming because astaxanthin cannot be synthesized de novo by shrimp, but it seems like they can metabolize these pigments (as $\beta$-carotene is abundant in microalgae) transforming them into astaxanthin (Moaka, 2011). Feeding experiments have shown that shrimp readily convert $\beta$-carotene and other dietary carotenoids into astaxanthin (Tanaka et al., 1976; Yamada et al., 1990). In this sense, astaxanthin levels found in shrimp reared under extensive conditions showed that the levels of this pigment do not come from the commercial feeds. It probably comes from the ponds' primary productivity since they become enriched with agricultural fertilizers, once a month, to increase primary productivity (i.e., phytoplankton rich in pigments) used as food complement along with the commercial feed. In shrimp reared under hyper-intensive conditions, small amounts of astaxanthin may have come from the pigments present in microorganisms (e.g., microalgae, bacteria, yeast) produced in the biofloc of the pond.

Moreover, astaxanthin deficiency could be the reason for the high mortalities ( $>20 \%$ ) observed in this rearing system, since organisms may be more susceptible to pathogens (Pan et al., 2003) and less resistant to physical and chemical changes (e.g., high temperatures or hypoxia) during farming (Menasveta $e t$ al., 1993). In addition to the physiological effects that 

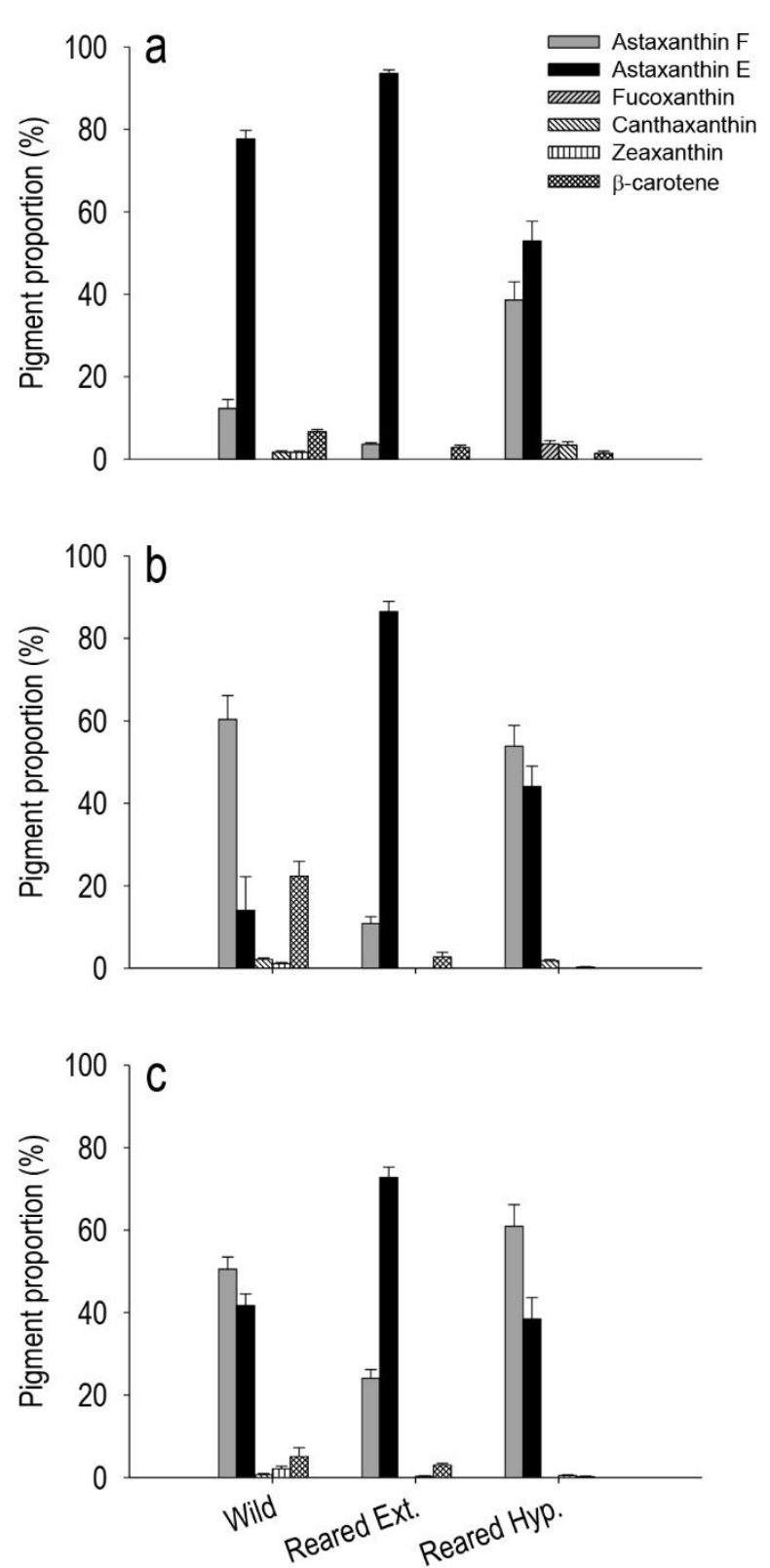

Figure 1. Pigment proportion (\%) in a) hepatopancreas, b) exoskeleton and c) muscle of $P$. vannamei captured in the wild and reared under extensive (Reared Ext.) and hyperintensive conditions (Reared Hyp.). Results are expressed as the mean \pm SE. Total shrimp analyzed $n=133$. F: free, E: esterified.

may be caused by the lack of inclusion of astaxanthin in commercial feeds. It may also harm the appearance of shrimp (coloration) since low accumulation levels of astaxanthin in the exoskeleton and muscle (Table 1) could produce a less intense orange color in cooked shrimp, compared to those that accumulate more astaxanthin (Arredondo-Figueroa et al., 2003).

Besides the availability of pigment-rich natural food in the ponds of aquaculture systems, it is possible that

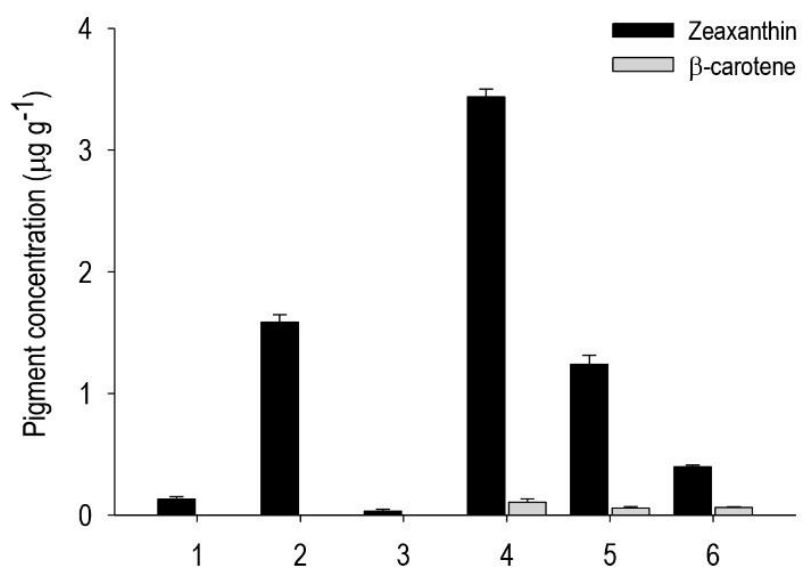

Figure 2. Pigment concentration $\left(\mu \mathrm{g} \mathrm{g}^{-1}\right)$ in commercial feeds used in extensive and hyper-intensive shrimp farming. 1) Pelletized for extensive conditions (Feed-Ext) with $30 \%$ protein (Brand A), 2) pelletized for hyperintensive conditions (Feed-Hyper) with $35 \%$ protein, 3) crumble Feed-Hyper with $35 \%$ protein, 4) Feed-Ext with $30 \%$ protein (Brand B), 5) Feed-Ext with $40 \%$ protein, and 6) Feed-Ext with $35 \%$ protein. Samples were analyzed by triplicate for each commercial feed.

rearing conditions control the ability of shrimp to metabolize some pigments into astaxanthin. It has been suggested that this capacity is only attributed to some species of yeast, bacteria, micro- and macroalgae, and terrestrial plants (Goodwin, 1980; Estermann, 1994; Moaka, 2011). Recently, it has been demonstrated that the diet component, environmental factors, and rearing conditions exert a particular effect on the microbiota composition in the gut of shrimp P. vannamei (CornejoGranados et al., 2017; Li et al., 2018). For instance, an important change in the gut microbiota of shrimp $P$. vannamei, including some genera of bacteria (Mycobacterium and Paracoccus) capable of carotenogenesis or biotransformation of some pigments into astaxanthin, have been observed under different rearing and feeding conditions (Enciso-Ibarra, 2016). It raises the possibility that previous works suggesting that shrimp are able of biotransformation of pigments into astaxanthin (Tanaka et al., 1976; Yamada et al., 1990) involved the presence of carotenogenic microbiota in the gut. Thus, efforts must be made to elucidate the specific effect of the gut microbiome on shrimp physiology.

Astaxanthin was not detected in the commercial feeds, not even in those used for hyper-intensive conditions where shrimp are not exposed to additional food from natural productivity of the ponds (as occurs under extensive rearing conditions), expecting that commercial feeds cover in full all the nutritional requirements of shrimp. It is odd the lack of carotenoids 
from animal resources since commercial brands claim that feeds contain bivalve mollusk and crustacean meals. Low amounts of zeaxanthin, lutein, and $\beta$ carotene, all presumably derived from terrestrial plant sources (Scott \& Alison, 2005) were instead found in commercial feeds (Fig. 2). Although shrimp can metabolize those pigments to produce astaxanthin (Moaka, 2011), the amounts of these pigments found in the commercial feeds were very low compared to pigment concentrations found in the tissues of $P$. vannamei. More recently, commercial brands have been using different natural (i.e., micro- and macroalgae, terrestrial plants as marigold flowers) and synthetic sources of carotenoids to produce balanced feed for different farmed aquatic animals. Differences among brands and within the same brand can be a result of both quality and quantity of the ingredients used to produce the feeds, but also to the manufacturing process, storage and management procedures, such as cooking and drying, which could reduce astaxanthin levels (Toyes-Vargas et al., 2016).

In conclusion, astaxanthin was mainly accumulated in hepatopancreas and lesser extent in exoskeleton and muscle of juveniles of $P$. vannamei. Also, the accumulation of astaxanthin depended on the rearing system and was not explained by commercial feeds for rearing shrimp. Primary productivity in the ponds or changes in the carotenogenic microbiome in the shrimp gut may explain the changes in the accumulation of astaxanthin in reared shrimp. The commercial feed used for farming shrimp lacks the principal carotenoid found in shrimp tissues, which could affect health condition of the organisms and rearing performance, as well as the reddish appearance, decreasing the commercial value of shrimp.

\section{ACKNOWLEDGMENTS}

Authors are grateful to Luis Humberto and Diana Madero López for their technical assistance during the sampling of juvenile shrimps and commercial feeds. A special thanks to anonymous reviewers for their comments that improved this manuscript. For your invaluable encourage a special thanks to ECN-SVHC. This research was supported by grants PROFAPI 2015/124 to M.A. Hurtado and CONACyT INFR2012-01-188065 to M.M. Manzano-Sarabia. The first author was supported by a scholarship ( $\mathrm{N}^{\circ} 446016$ ) from CONACYT.

\section{REFERENCES}

Arredondo-Figueroa, J.L., Pedro-Islas, R., Ponce-Palafox, J.T. \& Vernon-Carter, E.J. 2003. Pigmentation of
Pacific white shrimp (Litopenaeus vannamei, Boone 1931) with esterified and saponified carotenoids from red chili (Capsicum annum) in comparison to astaxanthin. Revista Mexicana de Ingeniería Química, 2: $101-108$.

Chew, B.P. 1995. Antioxidant vitamins affect food animal immunity and health. Journal of Nutrition, 125: 18041808.

Chien, Y.H. \& Jeng, S.C. 1992. Pigmentation of kuruma prawn, Penaeus japonicus Bate, by various pigment sources and levels and feeding regimes. Aquaculture, 102: 333-346.

Chien, Y.H., Chien, I.M., Pan, C.H. \& Kurmaly, K. 1999. Oxygen depletion stress on mortality and lethal course of juvenile tiger prawn Penaeus monodon fed a high level of dietary astaxanthin. Journal of the Fisheries Society of Taiwan, 26: 85-93.

Clarke, A. 1979. Lipid content and composition of the pink shrimp Pandalus montagui (Leach) (Crustacea: Decapoda). Journal of Experimental Marine Biology and Ecology, 38: 1-17.

Cornejo-Granados, F., López-Zavala, A.A., GallardoBecerra, L., Mendoza-Vargas, A., Sánchez, F., Vichido, R., Brieba, L.G., Viana, M.T., SoteloMundo, R. \& Ochoa-Leyva, A. 2017. Microbiome of Pacific whiteleg shrimp reveals differential bacterial community composition between wild, aquacultured and AHPND/EMS outbreak conditions. Nature, Scientific Reports, 7(11783): 1-15.

Dall, W., Smith, D.M. \& Moore, L.E. 1991. Biochemical composition of some prey species of Penaeus esculentus Haswell (Penaeidae: Decapoda). Aquaculture, 96: 151-166.

Dall, W., Smith, D.M. \& Moore, L.E. 1995. Carotenoids in the tiger prawn Penaeus esculentus during ovarian maturation. Marine Biology, 123: 435-441.

Enciso-Ibarra, K. 2016. Evaluación del cambio en la microbiota del contenido intestinal de camarón silvestre (Penaeus vannamei) sometido a diferentes condiciones de cultivo. M.SC. Thesis, Acuicultura. Centro de Investigación en Alimentación y Desarrollo, A.C., Unidad Mazatlán, 126 pp.

Estermann, R. 1994. Biological functions of carotenoids. Aquaculture, 124: 219-222.

Food and Agriculture Organization (FAO) 2018. Global aquaculture production 1950-2017. http://www.fao. org/fishery/statistics/global-aquaculture-production/ query/es. Reviewed 1 September 2018.

Foss, P., Storebakken, T., Schiedt, K., Liaaen-Jensen, S., Autreng, E. \& Streiff, K. 1984. Carotenoids in diets for salmonids: I. Pigmentation of rainbow trout with the individual optical isomers of astaxanthin in comparison with canthaxanthin. Aquaculture, 41: 213-226. 
Fisher, L.R., Kon, S.K. \& Thompson, S.Y. 1957. Vitamin A and carotenoids in certain invertebrates VI. Crustacea: Penaeidea. Journal of the Marine Biological Association of the United Kingdom, 36: 501-507.

Flores, M., Díaz, F., Medina, R., Re, A.D. \& Licea, A. 2007. Physiological, metabolic and haematological responses in white shrimp Litopenaeus vannamei (Boone) juveniles fed diets supplemented with astaxanthin acclimated to low-salinity water. Aquaculture, 38: 740-747.

Goodwin, T.W. 1980. The biochemistry of the carotenoids. Vol. 1. Plants. Chapman and Hall, London.

Goodwin, T.W. 1984. The biochemistry of the carotenoids. Vol. II. Animals. Chapman \& Hall, London.

Howell, B.K. \& Matthews, A.D. 1991. The carotenoids of wild and blue disease affected farmed tiger shrimp (Penaeus monodon, Fabricius). Comparative Biochemistry and Physiology, 98: 375-379.

Ju, Z.Y., Deng, D.F., Dominy, W.G. \& Forster, I.P. 2011. Pigmentation of Pacific white shrimp, Litopenaeus vannamei, by dietary astaxanthin extracted from Haematococcus pluvialis. Journal of the World Aquaculture Society, 42: 633-644.

Okada, S., Nur-E-Borhan, S.A. \& Yamaguchi, K. 1994. Carotenoid composition in the exoskeleton of commercial black tiger prawns. Fisheries Science, 60: 213-215.

Li, E., Xu, C., Wang, X., Wang, S., Zhao, Q., Zhang, M., Qin, J.G., \& Chen, L. 2018. Gut microbiota and its modulation for healthy farming of Pacific white shrimp Litopenaeus vannamei. Reviews in Fisheries Science \& Aquaculture, 26: 381-399.

Liñán-Cabello, M.A., Paniagua-Michel, J.J. \& ZentenoSavin, T. 2003. Carotenoids and retinal levels in captive and wild shrimp, Litopenaeus vannamei. Aquaculture Nutrition, 9: 383-389.

Menasveta, P., Worawattanamateekul, W., Latscha, T. \& Clark, S. 1993. Correction of black tiger prawn Penaeus monodon coloration by astaxanthin. Aquacultural Engineering, 12: 203-213.

Moaka, T. 2011. Carotenoids in marine animals. Marine Drugs, 9: 278-293.

Niu, J., Tian, L.X., Liu, Y.J., Yang, H.J., Ye, C.X., Gao, W. \& Mai, K. 2009. Effect of dietary astaxanthin on growth, survival and stress tolerance of postlarval shrimp, Litopenaeus vannamei. Journal of the World Aquaculture Society, 40: 795-802.

Received: 6 November 2018; Accepted: 5 December 2018
Pan, C.H., Chien, Y.H. \& Hunter, B. 2003. Alterations of antioxidant capacity and hepatopancreatic enzymes in Penaeus monodon (Fabricius) juveniles fed diets supplemented with astaxanthin and exposed to Vibrio damsela challenge. Journal of Fisheries Society of Taiwan, 30: 279-290.

Scheidt, K. 1990. New aspects of carotenoid metabolism in animals. In: Krinsky, N.I., Matthews-Roth, M.M. \& Taylor, R.F. (Eds.). Carotenoids: chemistry and biology. Plenum Press, New York, pp. 247-268.

Scott, E. \& Alison, L. 2005. Comparison of carotenoid content in fresh, frozen and canned corn. Journal of Food Composition and Analysis, 18: 551-559.

Shimidzu, N., Goto, M. \& Miki, W. 1996. Carotenoids as singlet oxygen quenchers in marine organisms. Fisheries Science, 62: 134-137.

Supamattaya, K., Kiriratnikom, S., Boonyaratpalin, M. \& Borowitzka, L. 2005. Effect of a Dunaliella extract on growth performance, health condition, immune response and disease resistance in black tiger shrimp (Penaeus monodon). Aquaculture, 248: 207-216.

Tanaka, Y., Matsuguchi, H., Katayama, T., Simpson, K.L. \& Chichester, C.O. 1976. The biosynthesis of astaxanthin-XVIII. The metabolism of the carotenoids in the prawn, Penaeus japonicus Bate. Bulletin of the Japanese Society for the Science of Fish, 42: 197-202.

Toyes-Vargas, E., Robles-Romo, A., Méndez, L. \& Palacios, E. 2016. Changes in fatty acids, sterols, pigments, lipid classes, and heavy metals of cooked or dried meals, compared to fresh marine by-products. Animal Feed Science and Technology, 221: 195-205.

Yamada, S., Tanaka, Y., Sameshima, M. \& Ito, Y. 1990. Pigmentation of prawn (Penaeus japonicus) with carotenoids: I. Effect of dietary astaxanthin, $\beta$ carotene, and canthaxanthin on pigmentation. Aquaculture, 87: 323-330.

Zapata, M., Rodríguez, F. \& Garrido, J.L. 2000. Separation of chlorophylls and carotenoids from marine phytoplankton: a new HPLC method using a reversed phase C8 column and pyridine- containing mobile phases. Marine Ecology Progress Series, 195: $29-45$.

Zhang, J., Liu, Y.J., Tian, L.X., Yang, H.J., Liang, G.Y., Yue, Y.R. \& Xu, D.H. 2013. Effects of dietary astaxanthin on growth, antioxidant capacity and gene expression in Pacific white shrimp Litopenaeus vannamei. Aquaculture Nutrition, 19: 917-927. 